\title{
Dimensions of the perceived value for wine from the perspective of Slovenian wine consumers
}

\author{
Sandra PESTAR BIZJAK ${ }^{1,2}$, Hristo HRISTOV ${ }^{1}$, Aleš KUHAR ${ }^{1}$
}

Dimensions of the perceived value for wine from the perspective of Slovenian wine consumers

Abstract: Perceived value is a subjective impression of the consumer about the value of a product or a service. There is a lack of research and understanding of Slovenian wine consumers preferences, while at the same time the importance of the Slovenian wine sector is increasing. 221 adults from the two biggest Slovenian winegrowing regions who at least occasionally consume and purchase wine were interviewed with a structured questionnaire. The Perval scale was used to measure and identify the factors (dimensions) of the perceived value for wine. Further, the relation between Slovenian winegrowing regions and the perceived value dimensions was investigated. It was shown that respondents from the two largest Slovenian winegrowing regions perceive three different dimensions of value for wine: quality-price, emotional-social, and a dimension where indicators for humane, environmental and region of origin factors highly correlated, and were therefore named terroir. We also found that respondents value Primorska winegrowing region the most, followed by Podravje and other wine regions. Both winegrowing regions correlate to terroir and quality-price value dimensions. It was also found which value dimensions are more important to different socio-demographic groups, which can give wine producers and wine-sellers some ideas on consumer segmentation and marketing strategy.

Key words: perceived value; wine; consumer; Perval scale; Slovenia; factor analysis
Received September 11, 2019; accepted January 3, 2020. Delo je prispelo 11. septembra 2019, sprejeto 3. januarja 2020.

Dimenzije zaznane vrednosti vina s perspektive slovenskih kupcev vina

Izvleček: Zaznana vrednost je subjektivna ocena potrošnika o vrednosti izdelka oziroma storitve. Ker v Sloveniji primanjkuje raziskav, ki bi pripomogle $\mathrm{k}$ boljšemu razumevanju izbire potrošnikov vina, hkrati pa vinarski sektor pridobiva na pomembnosti, je bila med 221 potrošniki iz dveh največjih vinorodnih dežel v Sloveniji, ki vsaj občasno pijejo in kupijo vino, opravljena raziskava. Za ugotavljanje števila dimenzij zaznane vrednosti vina je bila uporabljena lestvica Perval, nato pa nas je zanimala povezava med dimenzijami in različnimi vinorodnimi deželami. Ugotovili smo, da vprašani potrošniki ločijo tri dimenzije zaznane vrednosti vina in sicer kakovostno-cenovno, emocionalno-socialno in tretjo dimenzijo, kjer so močno korelirali indikatorji okoljskih in človeških faktorjev, ter indikatorji, ki opisujejo regijo porekla vina; in smo jo poimenovali terroir. Anketiranci najbolj cenijo vinorodno deželo Primorska, sledi Podravje in nato ostale vinorodne dežele. Obe omenjeni vinorodni deželi korelirata s kakovostno-cenovno in terroir dimenzijo zaznane vrednosti vina. Ugotovili smo tudi, katere dimenzije zaznane vrednosti so pomembnejše respondentom $\mathrm{z}$ določenimi socio-demografskimi značilnostmi, kar bo vinskim pridelovalcem in prodajalcem lahko dobro izhodišče za segmentacijo potrošnikov in oblikovanje marketinške strategije.

Ključne besede: zaznana vrednost; vino; potrošnik; lestvica Perval; Slovenija; faktorska analiza

1 University of Ljubljana, Biotechnical faculty, Department for animal science, Ljubljana, Slovenia

2 Corresponding author, e-mail: sandra@santei.si

Comment: This paper is part of first author's Ph.D. thesis, done in 2018 by the mentorship of assoc. prof. Aleš Kuhar, Ph.D., and co-mentorship of prof. Tatjana Košmerl, Ph.D. 


\section{INTRODUCTION}

Perceived value is the perception about the product (or service) by the consumers, rather than something objectively determined by the seller and these perceptions involve a trade-off between what the consumer receives and what she or he gives up in order to acquire and/or use a product (Woodruff, 1997). It is a subjective value from the perspective of the consumer and is not equal to objective value of the product (Zeithaml, 1988). According to Woodruff (1997), consumer value is the source for competitive advantage and, as a concept, it is moving beyond the focus just on the quality. A promising direction for research toward an enhanced understanding of value is the dual perspective of value measurement, which includes assessing (intra-variable approach) and linking (inter-variable approach) value dimensions to other related measures, where the main flow of effects moves from perceived quality and perceived price to perceived value, satisfaction and to loyalty (Gallarza et al., 2011).

Olson and Jacobi (1972) defined consumer value as a sum of intrinsic and extrinsic information about a product. Intrinsic characteristics are physical part of the product (colour, taste, smell, sweetness, etc.), while extrinsic characteristics are connected with the product, but are not a physical part of it (label, cork, brand name, region of origin etc.). They showed, that for determining the quality of the product, intrinsic features are more important than extrinsic.

Intrinsic and extrinsic features are important for the perception and willingness to buy in the case of wine. Agnoli et al. (2016) found, that intrinsic features are more important for more regular consumers who are more familiar with wines. The concept of consumer value differs also with regard to circumstances within which a consumer thinks about value; when making a purchasing decision (when extrinsic features are more important) or when experiencing product performance during or after use, when intrinsic features come first (Woodruff, 1997). Price can be an indicator of the products quality when there is no other information to imply quality of the product, when there are many similar products on the market and when the consumer does not know the price (Zeithaml, 1988).

Perceived value is closely connected to value proposition. A brand's value proposition is a statement of the functional, emotional and self-expressive benefits delivered by the brand that provide value to the consumer (Aaker, 1996). Aaker (1996) considers price separately, as the price could reduce the value proposition of the product, however it can at the same time imply its higher quality.
There are different classifications of value found in the literature. Generally, value is defined as a two- or multidimensional construct, however Lin et al. (2005) claim that both theories are inadequate and contradictory at some points. They explain perceived value as a secondary indirect construct, where components of value and cost, both of which are manifested by numerous indicators, work as indirect indicators of perceived value. Most authors consider value as a multidimensional construct, but the agreement on the number of dimensions has not yet been reached (Gallarza et al., 2011). Number of dimensions most likely depends on the consumer and on the type of product in question.

Sheth-Newman-Gross model, also known as the theory of consumption values, is one of the analytical cognitive models of consumer behaviour. According to this model the consumer choice is a function of multiple consumption values, which make differential contributions in any given choice situation. Consumption values are independent, and are defined as: functional value, which is the perceived utility acquired from an alternative's capacity for functional, utilitarian or physical performance and is presumed to be the primary driver of consumer choice; social value, which is the perceived utility acquired from an alternative's association with one or more specific social groups; emotional value is the perceived utility acquired from an alternative's capacity to arouse feelings or affective states; epistemic value is the perceived utility acquired from an alternative's capacity to arouse curiosity, provide novelty, and/or satisfy a desire for knowledge; and conditional value, which is defined as the perceived utility acquired by an alternative as the result of the specific situation or set of circumstances facing the choice maker (Sheth et al., 1991). Even products, generally thought to be of high functional value are frequently selected on the basis of their social or emotional value (for example cars, kitchen appliances etc.).

On the basis of the Sheth-Newman-Gross model of consumer behaviour (Sheth et al., 1991), Sweeney \& Soutar (2001) developed PERVAL, a multiple-item scale to assess consumers perception of value for different product types. The PERVAL scale consists of four dimensions, which are: functional/quality, emotional, social and price/value for money, and has been assessed for validity and reliability in assessing perceived value for different types of products (i.e. Orth et al., 2005; Sigala, 2006; Gill et al., 2007; Brown \& Mazzarol, 2009; Walsh et al., 2014...). The PERVAL scale was used to assess the perceived value for wine in U.S. in 2005 and has been adapted due to the nature of the product. Adjustments included the addition of an environmental and a humane dimension and re-phrasing of few items 
(Orth et al., 2005). The outcome was that the drivers of preference for wine in U.S. were: functional benefit/ quality, price/value for money, social benefit, emotional benefit, environmental benefit and humane benefit. The PERVAL scale had been previously used also in Slovenian environment, where the author found that region of origin has a significant influence on the perceived value of chicken salami, which found to be at least as important as the four elements of the marketing mix (Vukasović, 2010).

Our study aimed to identify the dimensions of perceived value for wine from the perspective of Slovenian wine consumers and understand how they influence wine purchasing decisions. We also wanted to understand how the preferences of Slovenian wine regions differ depending on the dimensions of the perceived value for wine. Finally, we aimed to understand if the dimensions of the perceived value for wine differ depending on the socio-demographics of the respondents; and in the conclusion part of the paper also to give wine producers some guidance based on our findings, which could improve their marketing impact.

\section{MATERIALS AND METHODS}

\subsection{QUALITATIVE RESEARCH}

Prior to conducting the quantitative market research, a series of focus group meetings were conducted in order to understand all aspects of the perceived value of wine from the perspective of Slovenian wine consumers. A test focus group, represented by seven participants was held in June 2011 to prepare questions for other focus groups in a language understandable to average wine drinkers. In July 2011, three focus groups were conducted with a total of 20 Slovenian wine consumers (seven, five and eight participants). Each focus group consisted of participants from different socioeconomic statuses and adult age groups. The main purpose was to obtain a set of indicators which would best describe the perceived value of wine from the perspective of Slovenian wine consumers so that, if required, we could upgrade the PERVAL scale for wine, which was previously used to study the perceived value of wine in a U.S. environment (Orth et al., 2005). Accordingly, the scale was updated by adding two indicators which were frequently mentioned during focus group discussions: "produced in a wine region that has the potential to produce high quality wines « and "produced in wine region with long wine-making tradition«. Focus group meetings were used as a basis to develop the questionnaire for the quantitative part of the study.

\subsection{QUANTITATIVE RESEARCH}

The data for the study were gathered in July and August 2016 from 221 Slovenian wine consumers, who were residents of two major Slovenian wine regions: 109 from the Primorska and 112 from the Podravje wine regions. The majority of high quality Slovenian wine is produced in the two biggest Slovenian wine regions, and while both have a long wine-making history and tradition, they belong to different wine zones ('Council regulation (EC) No $479 / 2008$ on the common organization of the market in wine'), and they consequently produce different varieties and styles of wines. The online questionnaire used in this study was pretested online on a sample of 20 respondents from each studied wine regions to ensure that no semantic and measurement problems existed. Data were gathered through an online questionnaire using 1KA online software (University of Ljubljana, Faculty of Social Sciences), by means of convenience sampling with respect to balance in age, gender and place of residence. A specialized market research service provider was contracted to recruit their panel of respondents by email according to the sampling requirements. The screening section of the questionnaire asked four inclusion questions: the respondents had to (a) be born and reside in one of the two studied wine regions, (b) be above 18 years of age, (c) drink wine at least once per month and d) buy wine at least twice per year. Wine professionals, winemakers and sommeliers were excluded with a subsequent exclusion question. Those who were included were administered the remainder of the questionnaire, which was divided into three sections relevant for this paper: (1) wine purchasing and consumption habits; (2) PERVAL measures and wine region preferences; and (3) socio-demographic questions. The response rate of the contacted respondents was $48 \%$.

\subsection{CONSTRUCTS MEASUREMENT}

To assess wine purchasing, consumption habits and socio-demographic characteristics of the sample, closed questions with one possible answer were used. Standard socio-demographic questions were used. To assess preferences for wine regions, 7-point Likert scale was used. The main focus of the study was to identify the dimensions of the perceived value for wine. Consumer perceived value was measured using the PERVAL scale, which was developed by Sweeney \& Soutar (2001) and adapted by Orth et al. (2005) to investigate the perceived value for wine, where it was validated in a U.S. environment as a six-factor scale. We adjusted 
the PERVAL scale by including two region of origin specific indicators, which were frequently mentioned during focus group discussions. We also re-phrased some of the claims due to semantic differences that were realized during focus group discussions to ensure the respondents would have a clear understanding of the claims. Our PERVAL scale consisted of 21 items, and a seven-point Likert scale ranging from 1 (strongly disagree) to 7 (strongly agree) was used to measure the intensity of all indicators.

\subsection{DATA ANALYSIS}

Analysis of wine purchasing and consumption habits were based on the type of variables and analyzed with t-test or chi-square test to understand the differences between the two studied wine regions. Exploratory factor analysis was used for the identification of number of factors in the PERVAL scale and confirmatory factor analysis was used to demonstrate the reliability and validity of the scale. To assess the connection between the dimensions of the perceived value for wine and socio-demographic data, Pearson's and Spearman's correlation coefficients were used. To calculate how the preferences towards different wine regions differ according to the dimensions of the perceived value for wine, multiple regression analysis was used. Preferences towards different winegrowing regions (measured on a Likert scale from 1 to 7) were independent variables, dependent variable was each dimension of the perceived value for wine.

\section{RESULTS AND DISCUSSION}

\subsection{SAMPLE DESCRIPTION}

Total sample consisted of $53 \%$ male and $47 \%$ female respondents. Average age of the respondent was close to 41 years of age, with most of them having at least secondary school education. $79 \%$ of respondents were living in a small town or village. $21 \%$ had below, $17 \%$ above, and the rest average monthly income relative to the national average. More than half of respondents from both wine regions (53\%)

Table 1: Socio-demographic characteristics of the sample $(n=221)$

\begin{tabular}{|c|c|c|c|c|c|c|c|}
\hline & & \multicolumn{4}{|c|}{$\begin{array}{l}\text { Primorska winegrowing Podravje winegrowing } \\
\text { region } \\
\text { region }\end{array}$} & \multicolumn{2}{|c|}{ Total sample } \\
\hline \multirow{2}{*}{\multicolumn{2}{|c|}{ Socio-demographic characteristics }} & & Column N & & Column & & Column N \\
\hline & & Count & & Count & $\mathrm{N} \%$ & Count & \\
\hline \multirow[t]{2}{*}{ Gender } & Male & 62 & 57 & 56 & 50 & 118 & 53 \\
\hline & Female & 47 & 43 & 56 & 50 & 103 & 47 \\
\hline \multirow[t]{4}{*}{ Employment status } & Student & 8 & 7 & 13 & 12 & 21 & 10 \\
\hline & Unemployed & 8 & 7 & 11 & 10 & 19 & 9 \\
\hline & Employed & 81 & 74 & 78 & 70 & 159 & 72 \\
\hline & Retired & 12 & 11 & 10 & 9 & 22 & 10 \\
\hline \multirow[t]{3}{*}{ Size of place of residence } & $\begin{array}{l}\text { Town (above } 100.000 \\
\text { inhabitants) }\end{array}$ & 9 & 8 & 37 & 33 & 46 & 21 \\
\hline & $\begin{array}{l}\text { Small town }(10.000- \\
100.000 \text { inhabitants })\end{array}$ & 34 & 32 & 20 & 18 & 54 & 25 \\
\hline & $\begin{array}{l}\text { Village (below } 10.000 \\
\text { inhabitants) }\end{array}$ & 64 & 60 & 54 & 49 & 118 & 54 \\
\hline \multirow[t]{3}{*}{ Education status } & High school and below & 41 & 38 & 48 & 43 & 89 & 40 \\
\hline & Graduate degree & 30 & 28 & 26 & 23 & 56 & 25 \\
\hline & Post-graduate degree & 38 & 35 & 38 & 34 & 76 & 34 \\
\hline \multirow[t]{3}{*}{ Monthly income } & Under average & 14 & 13 & 32 & 29 & 46 & 21 \\
\hline & Average & 73 & 68 & 62 & 56 & 135 & 62 \\
\hline & Above average & 20 & 19 & 17 & 15 & 37 & 17 \\
\hline
\end{tabular}

Values in the same row and subtable marked with bolded fonts are significantly different at $p<.05$ in the two-sided test of equality for column proportions. Tests assume equal variances. Tests are adjusted for all pairwise comparisons within a row of each innermost subtable using the Bonferroni correction. 
usually consumed white wines, $44 \%$ reds and less than $3 \%$ sparkling or rose wine. $48 \%$ of respondents most commonly purchased wine at the supermarket stores and $35 \%$ at winemakers. Average price of purchased wine was 8 EUR or below, highest number of respondents $(35 \%)$ in the last year usually bought wine for the price between 3 and 5 EUR. Looking at the preferences toward Slovenian winegrowing regions, we found that Primorska is the most preferred wine region $(\mathrm{M}=6.15 ; \mathrm{SD}=1.28)$, followed by wine region Podravje $(M=5.48 ; S D=1.45)$. Posavje and foreign wine regions were less preferred $(\mathrm{M}=4.59$; $\mathrm{SD}=1.61$; and $\mathrm{M}=4.35 ; \mathrm{SD}=1.61$, respectively). A comparison of socio-demographic characteristics of the respondents from the two winegrowing region samples indicates that samples were similar in relation to gender distribution, employment status and level of education. Some socio-demographic differences occurred due to demographic differences between the compared wine regions, namely size of place of residence and monthly income; significantly more respondents from winegrowing region Podravje had their monthly income below national average and more of them came from bigger town (table 1).

\subsection{VALIDITY AND RELIABILITY OF THE PER- VAL SCALE}

We conducted exploratory factor analysis using SPSS software version 21 to verify the reliability and uni-dimensionality of the constructs. Statistically significant Bartlett test of sphericity and the Kaiser-Meyer-Olkin (KMO) above the 0.5 threshold confirmed suitability of data for factor analysis (Sharifpour et al., 2014). By use of the scree diagram, three factors for perceived value of wine were extracted: quality-price (quality and price indicators were highly correlated), emotional-social (high correlation of social and emotional indicators) and a factor we named terroir, where indicators for region of origin, humane and environmental indicators were highly correlated. The mean importance of quality-price was $5.3(\mathrm{SD}=1.4)$, indicating that respondents paid most attention to the product's quality and price, followed by terroir $(\mathrm{M}=5.1 ; \mathrm{SD}=$ 1.6) and the factor explaining the emotional-social value of wine $(\mathrm{M}=3.1 ; \mathrm{SD}=1.7)$. The factor loadings on all items were significant and exceeded the desired 0.7 threshold (Hulland, 1999) except for four items with loadings above 0.6 ; which were expected to reflect important information and were thus kept in for further

Table 2: Quality of the PERVAL scale $(\mathrm{n}=221)$

\begin{tabular}{|c|c|c|c|c|}
\hline Constructs and items of the PERVAL scale (Crombach alpha) & Standardized loadings & $\%$ of Variance & CR & AVE \\
\hline Factor Terroir (0.9) & & 24.1 & 0.95 & 0.74 \\
\hline ...is produced in a wine region that has the potential... & 0.8 & & & \\
\hline ...is produced in an environmentlly friendly manner & 0.8 & & & \\
\hline ...is produced in wine region with long wine-making tradition & 0.8 & & & \\
\hline ...is crafted by dedicated individuals & 0.8 & & & \\
\hline ...is made from grapes under strictly controlled environment & 0.8 & & & \\
\hline ...is crafted by very special and unique experts & 0.8 & & & \\
\hline ...is made without polluting the environment & 0.6 & & & \\
\hline Factor Emotional-social (0.8) & & 14.5 & 0.9 & 0.7 \\
\hline ...improves the way I am perceived by others & 0.7 & & & \\
\hline ...gives its owner social approval & 0.9 & & & \\
\hline ...makes me feel good & 0.9 & & & \\
\hline ...would give me pleasure & 0.6 & & & \\
\hline Factor Quality-price (0.8) & & 12.7 & 0.87 & 0.62 \\
\hline ...has consistent quality & 0.6 & & & \\
\hline ...offers value for money & 0.8 & & & \\
\hline$\ldots$ is reasonably priced & 0.7 & & & \\
\hline$\ldots$ is a good product for the price & 0.6 & & & \\
\hline
\end{tabular}

Inexes of fit: $\chi 2(84)=178.62 ; \mathrm{p}<0.001 ; \mathrm{RMSEA}=0.07 ; \mathrm{NFI}=0.94 ; \mathrm{NNFI}=0.96 ; \mathrm{CFI}=0.97 ; \mathrm{IFI}=0.97 ; \mathrm{SRMR}=0.07$

$\mathrm{CR}=$ composite reliability coefficient, $\mathrm{AVE}=$ average variance extracted. 
analysis. The loadings for two indicators did not exceed 0.4 threshold and were excluded from further analysis. Cronbach's alpha for all factors was well above the desired 0.7 threshold. The variance explained by the three dimensions was satisfactory at $53 \%$. In addition to the reliability analyses, we used indexes to demonstrate the fit of model to the data, as demonstrated in Table 2. Confirmatory factor analysis was done with AMOS IBM 21 program with robust maximum likelihood method.

\subsection{DIMENSIONS OF THE PERCEIVED VALUE FOR WINE WITH REGARD TO WINE RE- GIONS}

Slovenian wine consumers perceive three different dimensions of value in wine: quality-price, emotional-social and a terroir dimension. In American paper from 2005 they found, that American consumers perceive six different dimensions of value for wine and those were: quality, price, emotional, social, environmental and humane dimension. In this research it was also shown that the consumers for which quality dimension is more important, prefer French wines, and those for which price is more important, prefer Californian and Australian wines (Orth et al., 2005). We were interested to find, which dimensions of the perceived value for wine Slovenian consumers link to which wine regions. The relationships between the dimensions of the perceived value for wine and preferences for different wine regions are depicted in Table 3.

We found that both wine regions, Primorska and Podravje, are associated with the terroir dimension of the perceived value for wine ( $\mathrm{p}<0.001$ for both wine regions), and quality-price dimension ( $\mathrm{p}<0.001$ for both regions), meaning that consumers, who value these two dimensions of the perceived value more, will rather choose wine from either of those two wine regions. Regression coefficient tells us, how much each of the perceived value dimension changes, if the preference for a wine region changes by one point. This means that wine region Podravje is more tightly connected with the terroir dimension of the per- ceived value for wine, than Primorska. Both wine regions are connected to the same extent also with quality-price dimension of the perceived value for wine. There is no connection between the preference for any wine region and emotional-social dimension and also, there is no connection between the wine region Posavje or foreign wine regions and any of the dimensions of the perceived value for wine. Despite the fact, that the overall preference is higher for Primorska wine region, the total sample believes that the same two value dimensions are important when purchasing wine from either Primorska or Podravje wine regions, namely terroir and quality-price. The respondents in our sample, who appreciate the terroir of wine more, would more likely choose wines from Podravje winegrowing region. It is possible that the respondents from our sample were not familiar enough with wines from region Posavje and foreign countries, and this could be the reason why these wines are not percieved as being connected with any of the studied value dimensions. Emotional-social was rated much lower than the other two value dimensions and it seems that to Slovenian consumers from our sample this dimension is so unimportant, that they do not consider it when choosing wine from any of the winegrowing regions. Another question is why American consumers consider five, and Slovenian consumers only three value dimensions while choosing wine. It is likely that because American consumers come from a more mature capitalist market, they are therefor more susceptible to a variety of marketing messages. On the other hand Slovenian wine consumers are more traditional, considering mainly the connection between the quality and price and the terroir of wine, meaning the region of origin and the tradition of the winegrowing region.

\subsection{DIMENSIONS OF THE PERCEIVED VALUE FOR WINE WITH REGARD TO SOCIO-DEMO- GRAPHIC CHARACTERISTICS}

Lastly, we aimed to understand if the dimensions of the perceived value for wine differ depending on the

Table 3: Connection between wine region preferences and dimensions of the perceived value for wine

\begin{tabular}{lllllll}
\hline Perceived value dimension & Terroir & & \multicolumn{2}{l}{ Emotional-social } & \multicolumn{2}{c}{ Quality-price } \\
\hline Constant & B & P-value & B & P-value & B & P-value \\
Primorska & 2.58 & $<0.001$ & 3.22 & $<0.001$ & 2.98 & $<0.001$ \\
Podravje & 0.25 & $<0.001$ & -0.094 & 0.172 & 0.2 & $<0.001$ \\
Posavje & 0.28 & $<0.001$ & 0.105 & 0.133 & 0.2 & -0.04 \\
Foreign wine regions & -0.11 & 0.061 & -0.014 & 0.819 & 0.001 \\
\hline
\end{tabular}

$\mathrm{B}=$ regression coefficient. 
Table 4: Relation between socio-demographics and perceived value for wine $(n=221)$

\begin{tabular}{lllll}
\hline Perceived value dimension & & Terroir & Emotional-social & Quality-price \\
\hline Age & Pearsons r & $\mathbf{0 . 1 5}$ & 0.07 & 0.08 \\
& P-value & $\mathbf{0 . 0 2 9}$ & 0.276 & 0.245 \\
\hline Number of persons in the hausehold & Pearsons r & -0.03 & 0.07 & -0.05 \\
& P-value & 0.646 & 0.335 & 0.448 \\
\hline Size of place of residence & Spearmans r & -0.01 & -0.04 & -0.02 \\
& P-value & 0.914 & 0.543 & 0.819 \\
\hline Education & Spearmans r & -0.04 & -0.10 & $-\mathbf{0 . 1 7}$ \\
& P-value & 0.589 & 0.124 & $\mathbf{0 . 0 1 3}$ \\
\hline Monthly income & Spearmans r & 0.05 & 0.01 & $\mathbf{0 . 1 4}$ \\
& P-value & 0.468 & 0.908 & $\mathbf{0 . 0 3 9}$ \\
\hline
\end{tabular}

socio-demographic characteristics of the respondents. We found that there is weak, but statistically significant connection between respondents age and terroir dimension of the perceived value for wine, meaning that older respondents value this dimension more than younger. We also found weak negative statistically significant link between education and monthly income and quality-price dimension of the perceived value for wine, meaning that for these consumers wine price or the ratio between quality and price is less important when purchasing wine. There were no differences in terms of consumers employment status and family status and the perceived value for wine (Table 4). These results are relevant when creating consumer segmentation, having in mind which are the most important consumer segments that are the basis for the creation of marketing strategy.

\section{CONCLUSIONS}

Our research demonstrated, that in the sample of Slovenian wine consumers from the two largest Slovenian winegrowing regions, who at least occasionally buy and drink wine, perceive three different dimensions of the perceived value for wine: quality-price, emotional-social and a dimension which we named "terroir", where the indicators for region of wine origin, humane and environmental claims highly correlated. Qualityprice and terroir dimensions were rated above five on a seven-point Likert scale, indicating that both dimensions are very important to Slovenian wine consumers. Emotional-social dimension was rated just over three, meaning that marketing strategy from wine-makers and wine-sellers should focus on supporting superior terroir and quality-price ratio messages.

Both, quality-price and terroir dimensions corre- lated with Primorska and Podravje wine regions, but not with others. When making wine purchasing decisions, older respondents give greater value to the terroir dimension, while respondents with higher education and income are less concerned with the quality-price ratio. We propose that these information are taken into account in order to improve consumer segmentation and targeting.

According to the methodological requirements of this research, while measuring the constructs of consumer regiocentrism and regional identity, only consumers from wine regions Primorska and Podravje were included. It would be interesting to check if the perception of other (non-winegrowing regions and the third Slovenian winegrowing region-Posavje) consumers with regard to the perceived value would differ or confirm our findings. Also, we suggest that future research does not focus only on wine purchasing in terms of where the wine is bought, but also on the wine choice at the point of consumption (restaurants, social events etc.).

\section{REFERENCES}

Aaker, D. A. (1996). Building strong brands. New York, The Free Press: 380 str. https://doi.org/10.1108/BFJ-05-2015-0181

Agnoli, L., Capitello, R., Begalli, D. (2016). Behind intention and behaviour: factors influencing wine consumption in a novice market. British Food Journal, 118(3), 660-678. https://doi.org/10.1108/BFJ-05-2015-0181

Brown, R. M., \& Mazzarol, T. W. (2009). The importance of institutional image to student satisfaction and loyalty within higher education. The Chronicle of Higher Education, 58, 81-95. https://doi.org/10.1007/s10734-008-9183-8

Gallarza, M. G., Gil-Saura, I., Holbrook, M. B. (2011). The value of value: further excursions on the meaning and role 
of customer value. Journal of Consumer Behaviour, 10(4), 179-191. https://doi.org/10.1002/cb.328

Gill, D., Byslma, B., Ouchan, R. (2007). Customer perceived value in a cellar door visit: the impact on behavioural intentions. International Journal of Wine Business Research, 19(4), 257-275. https://doi.org/10.1108/17511060710837418

Hulland, J. (1999). Use of partial least squares (PLS) in strategic management research: a review of four recent studies. Strategic Management Journal, 20(2), 195-204. https://doi. org/10.1002/(SICI)1097-0266(199902)20:2<195::AID$\mathrm{SMJ13}>3.0 . \mathrm{CO} ; 2-7$

Lin, C.-H., Sher, P. J., Shis, H.-Y. (2005). Past progress and future directions in conceptualizing customer perceived value. Journal of Service Management, 16(3), 318-336. https://doi.org/10.1108/09564230510613988

Olson, J. C., \& Jacoby, J. (1972). Cue utillization in the quality perception process. In M. Venkatesan (Eds.), Proceedings of the third annual conference of the association for consumer research (pp. 167-179). Chicago, IL, Association for Consumer Research. Retrieved from http://acrwebsite. org/volumes/11997/volumes/sv02/SV-02

Orth, U. R., McGarry, Wolf, M., Dodd, T. H. (2005). Dimensions of wine region equity and their impact on consumer preferences. Journal of Product and Brand Management, 14(2), 88-97. https://doi.org/10.1108/10610420510592563

Sharifpour, M., Walters, G., Ritchie, B. W., Winter, C. (2014). Investigating the role of prior knowledge in tourist decision making: a structural equation model of risk percep- tions and information search. Journal of Travel Research, 20(10), 1-16. https://doi.org/10.1177/0047287513500390

Sheth, J. N., Newman, B. I., Gross, B. L. (1991). Why we buy what we buy: a theory of consumption values. Journal of Business Research, 22(2), 159-170. https://doi. org/10.1016/0148-2963(91)90050-8

Sigala, M. (2006). Mass customisation implementation models and customer value in mobile phone services. Preliminary findings from Greece. Managing Service Quality, 16(4), 395-420. https://doi.org/10.1108/09604520610675720

Sweeney, J. C., \& Soutar, G. N. (2001). Consumer perceived value: the development of a multiple item scale. Journal of Retailing, 77, 203-220. https://doi.org/10.1016/S00224359(01)00041-0

Vukasović, T. (2010). Model povezav med poreklom izdelka in zaznano vrednostjo blagovne znamke. Doctoral dissertation. Koper, Univerza na Primorskem, Fakulteta za management.

Walsh, G., Shiu, E., Hassan, L. M. (2014). Replicating, validating, and reducing the length of the consumer perceived value scale. Journal of Business Research, 67(3), 260-267. https://doi.org/10.1016/j.jbusres.2013.05.012

Woodruff, R. B. (1997). Customer value: the next source for competitive advantage. Academy of Marketing Science, 25(2), 139-53. https://doi.org/10.1007/BF02894350

Zeithaml, V. A. (1988). Consumer perceptions of price, quality, and value: a means-end model and synthesis of evidence. Journal of Marketing, 52(3), 2-22. https://doi. org/10.1177/002224298805200302 